\title{
Historein
}

Vol 8 (2008)

Performing Emotions: Historical and Anthropological Sites of Affect

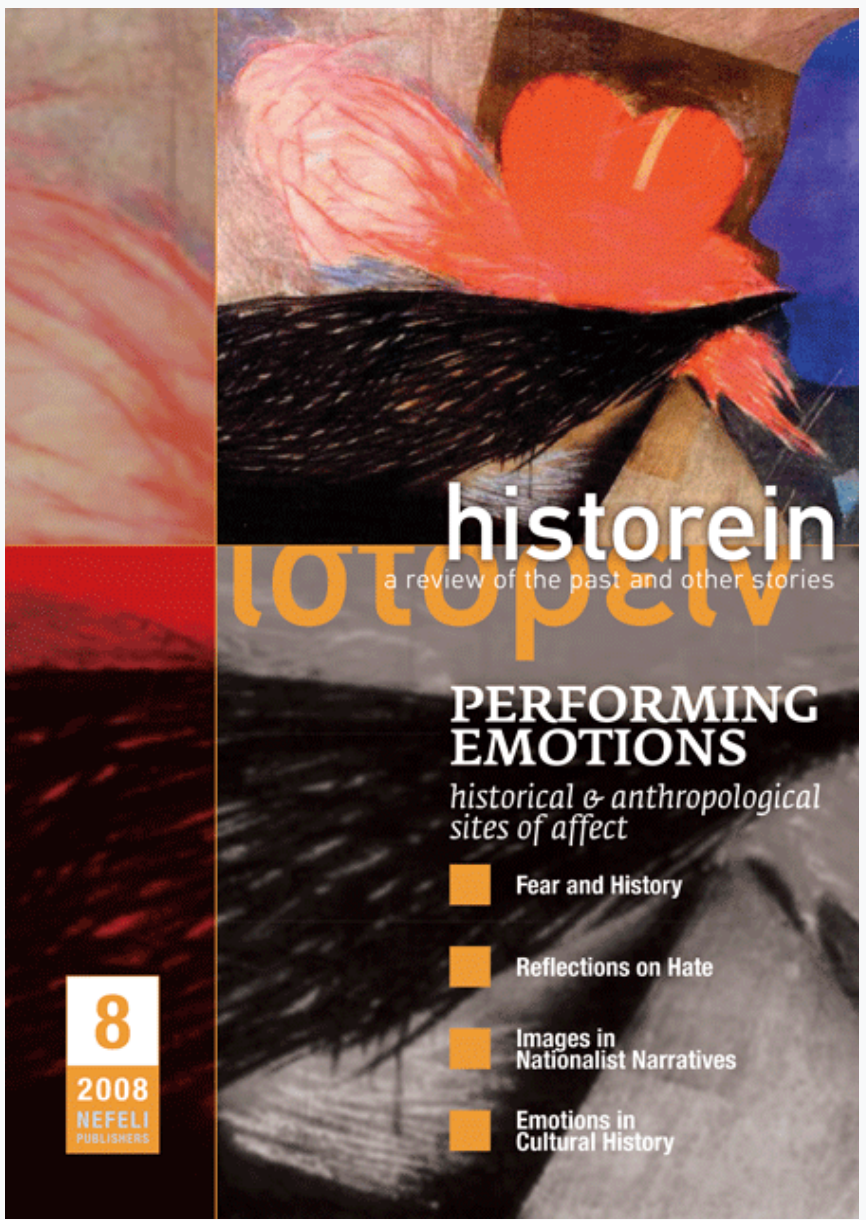

\section{Emotional Forces in Historical Thinking: Some Metahistorical Reflections and the Case of Mourning}

Jörn Rüsen

doi: $10.12681 /$ historein.36

Copyright @ 2012, Jörn Rüsen

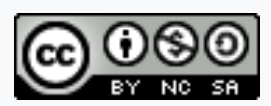

This work is licensed under a Creative Commons Attribution-NonCommercialShareAlike 4.0.

To cite this article:

Rüsen, J. (2012). Emotional Forces in Historical Thinking: Some Metahistorical Reflections and the Case of Mourning. Historein, 8, 41-53. https://doi.org/10.12681/historein.36 
Truly:

If two men take up arms against

each other

He who mourns will win.

-Lao-Tse ${ }^{1}$

In this article I intend to analyse the role of emotions in the mental processes of historical thinking. At first sight 'thinking' seems to be something essentially different from emotion. It strictly runs against the widespread mentality held by scholars that emotions are biased and subjective, whereas cognition at least has the possibility of more intersubjective validity (traditionally called objectivity). But this is a wrong impression. Thinking, as a cognitive procedure, is, of course, different from the feelings that go along with this process, but, nevertheless, both dimensions of the human mind are intertwined to a degree that we are not normally aware of.

Let me start with a single observation. In asking about emotions in historical thinking, we have to look at historiography, of course. It is the primary document, the 'source', that we have to consult. Here historians express their feelings, and it is rather easy to show how these feelings shape their presentation. Ranke, for instance, once expressed a very interesting emotion when he started a lecture on "Modern History since the Peace of Westphalia", held in 1847. Here he wanted to present his "standpoint", which he believed lay "in the realm of general thinking, of the conflict of leading opinions, which move his discipline". He spoke of "method" and of "the scientific perception of universal history". And it is in this context that he said that the impression of the simple facts of the past created an impression of feeling "wretched", of having a

\section{Emotional Forces in}

\section{Historical Thinking:}

Some Metahistorical

\author{
Reflections and the
}

Case of Mourning

\section{Jörn Rüsen}

Kulturwissenschaftliches Institut, Essen 
"feeling for the voidness of all things and a disgust for the many heinous crimes by which men have stained themselves". 'Starting from this emotion Ranke developed his idea of a highly meaningful essence in these disturbing events. "History does not simply open up the realm of fleeting appearances, but that of the abiding spirit." It is evident that within his conceptual framework of interpretation his "feeling of voidness" has disappeared.

Here we see an internal interrelationship between emotions and cognitive elements in historical thinking at the level of its fundamental pattern of significance. It is this interrelationship which allows us to understand Ranke's idea of universal history as an attempt to dissolve or overcome a fundamental experience of suffering. Suffering melts away under the sun of the idea that the events of the past in their temporal sequence testify to "the living God and the living men" being closely interrelated. The cognitive work of the historian serves to suppress a primary disturbing awareness of suffering and pain. Without the expression of his disturbing emotions we could not understand a very important element in Ranke's historical thinking, which I would like to call a fundamental forgetfulness of suffering.

Ranke's case is not unique. On the contrary: this transformation of an emotionally destructive experience of history into a cognitively constructive interpretation seems to be typical for the origins of modern historical thinking in the early philosophy of history (if not for Western historical thinking in general). ${ }^{4}$ Kant, who was one of the first to conceptualise the philosophy of history as a new way of understanding the past at the watershed to modernity, clearly expressed this destructive feeling: "It is hard to suppress a certain disgust when contemplating men's action upon the world stage. For one finds, in spite of apparent wisdom in detail, that everything, taken as a whole, is interwoven with stupidity, childish vanity, often with childish viciousness and destructiveness. In the end, one does not know what kind of conception one should have of our species, which is so conceited about its superior qualities." ${ }^{.5}$ And it was exactly in this context that he developed the idea of progress as the leitmotiv in which the past leads into a better future. "A philosophical attempt to write a general world history according to a plan of nature that aims at a perfect civic association of mankind must be considered possible and even helpful to this intention of nature."' The same way of feeling and thinking can be found in Herder's philosophy of history. "We tread the dust of our forefathers and walk on the sunken rubble of destroyed human constitutions and kingdoms ... Thus man doubts and despairs, ... the whole surface of the events of the world speak for this sad lamentation." ${ }^{7}$ Nevertheless, Herder thinks that historical thinking is able to pierce the surface of historical experience and to reveal the sense-bearing depths of universal history: "The immortal totality survives the pains of the vanishing parts and learns good from evil... We see a principle effective in all, namely human reason, which strives to create the one out of the many, order out of disorder, a whole with regularity and permanent beauty

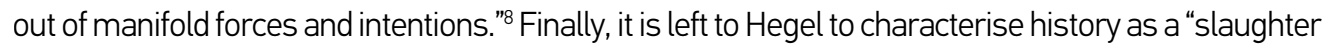
bench", to which the only adequate reaction is "the deepest and most helpless mourning" and "deepest compassion for nameless misery". ${ }^{9}$ Reflecting this impression in the realm of human reason meant for Hegel the transformation of feelings into thoughts, thus leaving behind the horrors of the past in favour of the pleasure of understanding history as the progress of human freedom. Human suffering only appears as a means to a higher purpose.

It is easy to present a lot of evidence as to what degree and in what form emotions constitute the mental process of historical sense-generation. It transforms the events of the past into a meaningful 
history for the present and its future perspective. This is seductive and worthwhile for our understanding of what historians do in order to follow the course of the history of historical thinking concerning this miraculous transformation of emotions into cognition. Emotions challenged by the perception of what happened were transformed, as mere facts, into the cognition of what really happened (as in Ranke's famous phrase that he simply wanted to show how things really happened)..$^{10}$ But I will not go deeper into this history. Instead, I would like to give a metahistorical argumentation which underlines this constitutive role of emotions. And, at the end, I would like give an example of not neglecting the inspiring quality of emotions and accepting their transforming into cognition. It is the case of mourning in history, which may demonstrate that emotions and cognition are two sides of the same coin.

In order to do so, I would like to start with a more general epistemological or even metaphysical argumentation concerning the interrelationship between feeling and thinking, emotion and cognition. As academics we tend to emphasise the importance of thinking and arguing by using concepts and ideas which have a cognitive nature. We tend to understand the emotions (even our own) which go along with the cognitive procedures of historical thinking as something additional, but non-essential, a kind of a background music that has no real function in our work.

In order to overcome this grossly misleading understanding of the role of emotions in human cognition, I would like to present a contradicting example. It stands for the fact that emotions not only constitute cognition, but allow for more insight than cognition can ever bring about. I refer to the famous part in Marcel Proust's novel $A$ la recherche du temps perdu (1913) where he describes an extraordinary emotional experience on the part of the narrator, while dipping little madeleine cookies into a cup of tea. "A shudder ran through me ... An exquisite pleasure had invaded my senses, something isolated, detached, with no suggestion of its origin. And at once the vicissitudes of life had become indifferent to me, its disasters innocuous, its brevity illusory - this new sensation having had on me the effect which love has of filling me with the precious essence, or rather this essence was not in me, it was me ... I begin to ask myself what it could have been, this unremembered state which brought with it no logical proof, but the indisputable evidence of its felicity, its reality, and in whose presence other states of consciousness melted and vanished."11

Here emotion transgresses cognition by presenting an insight into the reality of the world including the reality of the feeling subject, - an insight, that can never be reached by cognitive procedures. It is an emotion which leads the feeling person beyond the realm of logic. But this does not mean that it presents something irrational. On the contrary: it presents enlightenment, an awareness of the essence of the inseparable unity of the world and the human being. This fundamental overwhelming awareness (we can, if we like, even call it 'absolute') is realised with the power of an emotive force of the human mind which is recognised as the constitutive and leading aim of thinking itself. In the light of this emotional experience, thinking and cognition appear only as a search for a lost emotion which will never reach its destination.

I am grateful that such a rehabilitation of emotions from their traditional underestimation has occurred, in order to understand the mental process of historical sense-generation.

In order to make clear that emotions indeed play a constitutive role in this process, I would like 
to start with a general idea of what human sense-generation is about. Sense-generation means that humans have to understand and interpret their world and themselves in order to be able to live in it, and with themselves and the others with whom they have to live together. This mental process of sense-generation consists of four different procedures and their interrelationship. In a very abstract form one can say that it starts with perception, proceeds to interpretation, brings the interpreted perception into the general pattern of cultural orientation and provides the actionguiding will with its meaningful intentions, its aims and purposes. The orientation procedure can be divided (artificially) into parts: the orientation of human beings to the world, and the orientation of the human beings to the realm of their own subjectivity. All procedures share a common sensecriterion which keeps them together and guarantees a coherent interrelationship. This abstract scheme can easily be applied to the specific procedures of historical sense-generation.

This process of making sense of the past starts (in this abstract, schematic idea) with the perception of the past. Evidently, emotions play an enormous role in perceiving the past as something demanding interpretation, demanding interpretation as history. Emotions open up the realm of the past. ${ }^{12}$

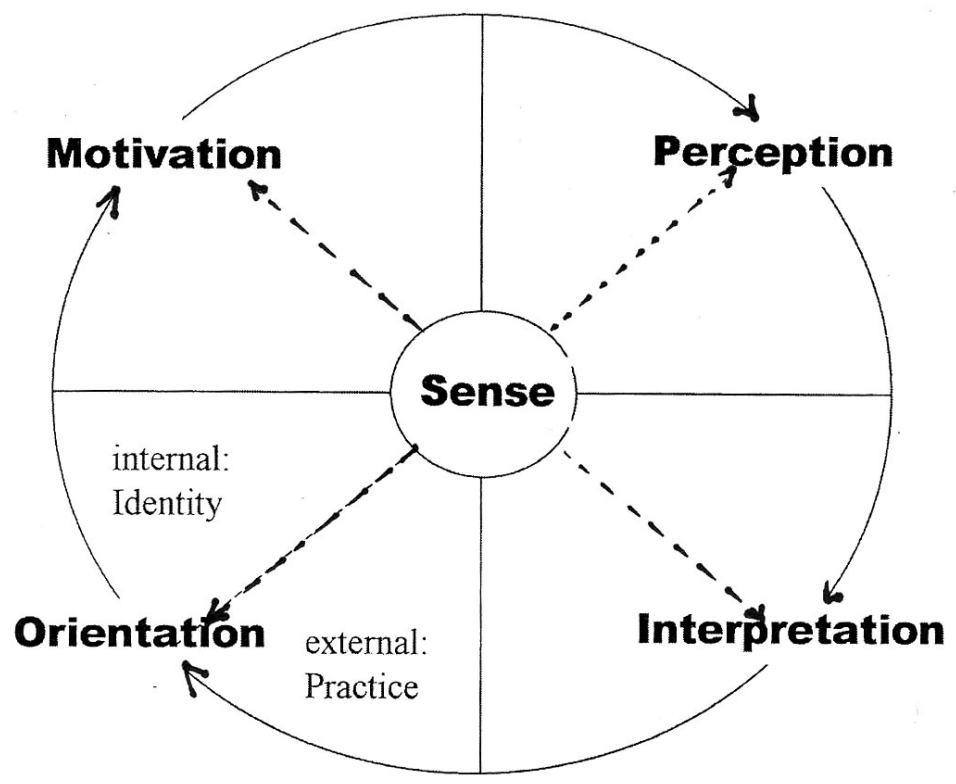

Figure 1. Diagram of the procedures of sense-generation

They transport it, so to speak, to the human mind and in doing so they prepare it for interpretation by giving it a precognitive meaning, with which it challenges the cognitive power of the human mind. Interpretation translates this precognitive 'disclosedness' (Erschlossenheit) into cognitive features.

Historical cognition, resulting from this interpretation, can only fulfil its orienting function in practical life if it is furnished with elements of representation. Historical representation, as it is done in historiography, does not only speak to the cognitive realm of the human mind, but to the human mind in general, including its emotive and volitive dimensions. In this procedure of orientation emotions become manifest in the aesthetic and rhetoric form of historical knowledge. ${ }^{13}$ 
This emotive form of historical representation can be easily made clear as regards the internal orientation to human subjectivity by history. The mental pattern of orientation by history in this invisible realm of human subjectivity can be called historical identity. Nobody can deny the power of emotions in the mental processes of identity formation by historical representation. But it is important to know that these emotions featuring identity are inseparably synthesised with elements of interpretation. It is the mental process of narrating a story which synthesises them. The story itself can be described as the master narrative of oneself, be it the (auto-)biography of a person or the master narrative of a community.

The last procedure in sense-generation is the motivation of the human will with aims and purposes, which gives its driving force a direction (thus fulfilling the role of ideas in influencing human activity, which Max Weber described as "Weichenstellung" [setting the course]). ${ }^{14}$ Here the emotive force of historical orientation is evident. We all know that people can kill others while following the national or ethnic master narrative inscribed on their minds. Ethnic cleansing always needs a historical framework which decides who should be killed, and this framework is the result of historical sense-generation.

So far, I have concentrated my argumentation on presenting the role of emotions in the mental processes of historical sense-generation. The cognitive factor has been mentioned but not explicated in its own constitutive importance. Just one remark: the cognitive elements are necessary as a complement to the emotive side of historical sense. Sense is both: something for the senses and therefore emotional, and something for the mind, and that makes it cognitive, in any case. In the academic or broader sense of the word, the 'scientific' character of historical studies is based on this cognitive element in historical sense-generation. Historical studies, as an academic discipline, gives these cognitive elements a certain form: it shapes them by methodical procedures of research. Interpretation is a cognitive procedure and cannot be dissolved in the essentially aesthetic and rhetoric procedures of historical representation.

Nevertheless, cognition has its limits and emotion can transgress them. In order to make this plausible, I would like to come back to the example by Marcel Proust. I think that there is an element or even a dimension in historical sense-generation which comes close to the precognitive insight Marcel Proust described. Indeed, there is a considerable precognitive dimension to historical sense-generation that lies beyond any possibility of being translated into cognitive structures and that, at the same time, presents a necessary condition for the idea of the utmost fulfilment of historical sense-generation.

In order to make this clear, it is useful to distinguish between three levels of historical sense-generation. The first one is the functional level, the level of practical life: here historical sense-generation is a cultural fact in social life. History is embodied in habits, manners and social activities. Here the past is already present in a meaningful way, conditioning present-day life, influencing cultural orientation, preshaping possibilities of historical identity, etc. (We are used to thinking that history is only a construction. But we overlook the fact that before we construct it by the mental procedures of sense-generation, the constructors are already constructed by the past, which is present in the conditions and influences under which his or her work of historical representation is done.) 
The second level is the level of construction or of theoretical reflection: here deliberate activities of the human mind take place; historians pursue their work, monuments are erected, etc. The third level mediates between the first and the second. It is the level of pragmatic reflection and practical interference. Here the result of the historian's work, the 'constructed history', is applied to practical life. It is the level of education, the place of the politics of identity and of the political struggle over different interpretations of common goals, etc.

\begin{tabular}{|l|l|}
\hline $\begin{array}{l}\text { (A) Functional level of } \\
\text { practical life }\end{array}$ & $\begin{array}{l}\text { History as the presence of the past is a concrete social fact in the circum- } \\
\text { stances of human life by virtue of its pre-given sense criteria and disposi- } \\
\text { tions in the mentality of the people. It conditions ('constructs') the work of } \\
\text { historians. }\end{array}$ \\
\hline $\begin{array}{l}\text { (B) Mediating level of } \\
\text { pragmatic interference } \\
\text { and reflection }\end{array}$ & $\begin{array}{l}\text { History as a pre-given fact of cultural orientation in social life is picked up } \\
\text { as an element of evidence and experience and becomes a matter of inter- } \\
\text { pretation. History as a result of mental activities is brought into practical } \\
\text { life and addresses its embodied history. It works on, confirms, criticises or } \\
\text { changes it. }\end{array}$ \\
\hline $\begin{array}{l}\text { (C) Level of theoretical } \\
\text { reflection }\end{array}$ & $\begin{array}{l}\text { History is a result of a mental activity, of making sense of the past in order } \\
\text { to understand the present and to expect and project the future. It is a matter } \\
\text { of 'construction'. }\end{array}$ \\
\hline
\end{tabular}

Table 1: Levels of historical consciousness

Let us look at the interrelationship of these three levels and how history is done there. We see that in practical life the pre-given history always challenges people to reflect it, interpret it, and to give it meaning and significance. Historical sense is embodied in social reality, but only in such a way that it has to be picked up and worked through, completed and changed. Mediating the results of this world of theory into practical life is a procedure which (subsequently) can be understood as a historical process in its own right. This historical process has an epistemological peculiarity. It can never be conceptualised on the level of construction. It happens on the blind spot of historical thinking. So, history takes place through and beyond the procedures of historical sense-generation. The process of sense-generation follows this history but can never reach it. Nevertheless, it is exactly this history which is the most 'actual', the most lively, and, I dare say, the most historical. It is, at least, the most real one, since it is a procedure of the life-world of historians themselves, and the life-world is the most real reality for us humans. The ontological and epistemological character of history as a life-world may be described by the philosophical term of Unvordenklichkeit (literally unprethinkability, which means precognitive and unthinkable at the same time).

Is there a way to access this living, most historical history? Since it cannot be conceptualised by cognitive means, it cannot be constructed as it happens; the only access is the precognitive, and that brings us back to emotion.

Sometimes historians describe enlightening moments that stimulate them as intuition in a most elementary and effective way. I imagine that these intuitions stem from this un- and prethinkable history which is pursued by the process of historical sense-generation. But these are very rare moments and many historians overlook or even do not experience them in following the main roads 
of pre-established paradigms of historical research and historiography. Nevertheless, we cannot think about the work of historians without presupposing that they believe in the possibility of generating sense out of the perception of the past from its core, namely the reality of the past in the midst of our life-world. This belief is unvordenklich (unprethinkable). As such, it is an emotional condition without which the work of historians would be impossible. So, even the smallest trace of madeleine cookies are present in the work of historians; and they should dip them more frequently into the tea of their metahistory in order to gain more powerful intuition for their work.

I would like to end my argumentation with an example of an emotion which should play a much more important role in historical thinking than we are accustomed. I think of mourning as a necessary factor of historical sense generation, in that the challenge of traumatic historical events presents an adequate answer. ${ }^{15}$ I tackle this issue not in order to distinguish between emotion and cognition but to show how they can form a synthesis.

In order to make this plausible, I shall start with a short explication of what I mean by a traumatic historical experience. ${ }^{16}$ Experiences of the past which negate and even destroy the possibility of giving them a historical meaning are traumatic. A past gets its historical meaning by relating it to the cultural orientation of present-day life. The past becomes history if it is interpreted within a categorical framework of a time concept that relates it to the present, to its needs for understanding its temporal order and to the changes which have taken place. This interpretation bears the necessity of projecting a future perspective for human activity. History is an interrelationship between past, present and future, brought about by an interpretation of the experience of the past. History, therefore, brings past, present and future into a meaningful coherence. This coherence is constituted by the principles of historical sense and meaning. Trauma is a certain quality of the experience of the past. Past events are traumatic when they negate and even destroy these principles. Trauma in history breaks the coherence of the fundamental historical interrelationship between past, present and future. One can generalise Dan Diner's description of the Holocaust being a fracture of civilisation ${ }^{17}$ into a general meaning of trauma as an element of historical experience: it constitutes a "broken time" in the categorical approach of historical interpretation. ${ }^{18}$

Historical events with a traumatic character confront historians with a borderline experience. They cannot be held within the realm of objective data, but they penetrate the realm where they are interpreted. Today, we think that interpretation is a construction of meaning that we have imposed on the facts..$^{19}$ In respect to traumatic experiences, we can see that historians' work of making sense of the past is more than just providing a meaning afterwards: the facts themselves can destroy or deconstruct the meaning of their interpretation. In this case, historians do not make sense of the past, but the past has become senselessness for historians.

Trauma in history means that the work of historians proves impossible as long as they do not find an interpretative answer to this borderline character of the past, conditioning the sense criteria of its interpretation in a negative and destructive way.

The first reaction to trauma is silence. But historians have to speak about the past, unless they want to give up their profession. If they do their duty as historians and they make sense of the 
past, and if this is done by including its traumatic elements, history then pursues a detraumatisation of these elements by virtue of interpreting them.

There are different ways of historical detraumatisation (although this is not my point here). I would like to problematise it in a more fundamental way: Does historical interpretation not distort the specific character of the past with which it is concerned?

My answer is yes, it does as long as there is no attempt at interpreting and representing the disturbing experiences of the past in its traumatic character. That does not mean stopping to think about and to express the horrific senselessness by remaining silent or by moving the events from the field of history into that of myth. Instead, we have to look for and to realise the mode of historical thinking that corresponds to the sense-destructing meaning.

Trauma destroys meaning. Its historical interpretation has to realise this very loss of meaning vis-à-vis what has actually happened. This is the door through which mourning enters the work of the historians..$^{20}$

At first glance history has nothing to do with mourning. Mourning is emotional and related to losses which have recently happened. History is cognitive and related to a remote past. This impression is misleading, however, since history and mourning have something essential in common: both are procedures of memory and committed to its logic of sense generation.

Mourning is a mental procedure of commemorating somebody or something lost. The loss has the specific character of personal loss with the passing of a beloved person or something. The purpose of this mode of commemoration is to regain oneself by "working through" the loss (in the words of Sigmund Freud). Regaining oneself means to come back to life through the death of the beloved person or object. In a certain way even the lost subject or object comes back: it comes back in the form of the presence of absence, which enlarges the mental horizon of the mourner through elements of transcendence.

The archaic paradigm for this mental procedure, which, of course, is a procedure of social communication, is the ritual which transforms the dead person into an ancestor. As ancestors, the dead get a new form of life, which is invisible but very powerful. ${ }^{21}$ This mental, personal and social practice can easily be applied to history (astonishingly, this has not yet been done).

While I do not think that history today is ancestor worship, it does have some logical similarity with it: we should realise that historical thinking itself, by its very logic, follows the logic of mourning, at least partly in a formal way; it renders the absent past, which is a part of one's own identity, present again. ${ }^{22}$ In fact, only the very past that is important for the people of the present has to become history. This importance of the past can be characterised as its relevance for the essence of the people of today, for their identity. Identity is an issue of historical consciousness. If we realise this, the past in the mental procedures of historical consciousness is essentially related to the group of people who feel that they belong together and are different from others. In respect to the identity of a person or a group, the past has nothing to do with the outside world, 
nor is it external, but it is an issue relevant to the internal life of the human subject. The past has a relationship to human subjectivity which can be compared with the power of deceased persons or objects in the mourning process.

When we think about history in this relationship with human subjectivity, it becomes obvious that historical consciousness renders the absent past, which is a part of one's own identity, present. And exactly this is brought about by mourning. So, in a simple logical argumentation, one can say that mourning is constitutive for historical thinking in general and in principle. If those who have passed away are in a positive relationship to the self-esteem of the people of today (and that is a normal and usual relationship of historical consciousness all over the world), the remembrance of them keeps alive or enlivens them through their death. To bring it to the point: in historical consciousness the dead are still alive. And what makes them alive? What else but mourning?

I think that metahistory has completely overlooked this constitutive role of mourning in the procedures of historical memory. History renders the absence of the past to which the people of the present are related as an element of their own selves present again. That is exactly what happens in mourning: something, a subject or an object to which the living person is deeply related as a factor of his or her own self, passes away. This passing away endangers the related person or people of losing themselves. They feel they are being towed away by this passing away and they have to struggle to come back to themselves. This struggle is the mourning process.

In history we have a similar relationship between past and present: what has passed away is relevant for the self-esteem and the self-understanding of the people of today and they have to regain themselves by making the absent, their passed-away world, present again. The difference between history and mourning lies, of course, in the character of this regaining of oneself. In the case of mourning, it is painful and bitter. The experienced loss opens a wound in the mind. History, on the contrary, seems to be a procedure of remembrance, which does not have this painful element, but it is pursued as a gain, as taking over a heritage, as bringing about self-esteem. But if the past of which history speaks has this relevant relationship with identity, can we even think of its passing away as something which does not hurt? Does it not leave an open gap to be filled by mental activity? I think it is worthwhile considering whether the procedures of historical consciousness are grounded in a mourning-like process. This process seems to be covered by an attitude in which the passing away has lost its pangs and has got another quality: that of independent fact-like things which can be picked up and integrated into the properties of oneself.

So, mourning as an issue of metahistory means, first of all, the recognition of the fact that there is a basic element of mourning in historical consciousness. It is normally overlooked, since the aspect of inheriting the past and the idea that it belongs to us and that we continue and develop further its work, are dominant. Given this positive relationship of the past and the present in historical consciousness, forming one's own personal and collective identity is only possible if the loss has been overcome. Since this loss inevitably and happens permanently with the change of generations, it creates the past in the continuous passing away of the human world. This past has to become history. As history, the absent past becomes present again. Since the procedure of this passing away and overcoming it hurts, it is structurally forgotten in the act of doing history. 
The most frequent mode of this forgetting is the idea that history is a subject matter of interpretation, a raw material, onto which we impose our meaning. This is evidently the case in the approach of professional historians of thinking history as a reified pre-givenness of the experience of the past. Here, history is something to be disclosed in the source material by going into the archives and finding out what actually happened.

So we have to look behind this abstract and alienated relationship between the historian as a researcher, on the one hand, and his or her source materials, on the other. We have to analyse the precondition for a meaningful relationship between past and present - called 'history'. There is a precognitive interrelationship between the past and the present. The past is already present in the topical life procedures, where 'history' as a cultural practice takes place. Here, where the past is living in the circumstances and conditions of human activity and suffering, mourning as a mode of historical thinking is rooted.

I would like to illustrate this by the issue of humankind as a constitutive factor of historical identity. A historical experience which negates the universal validity of the category of humankind by depriving individuals of their status as human beings touches the very heart of all identity concepts based on the category of humankind. If this negation is executed physically, one's own individuality is destroyed in its universalistic historical dimension. Then the persuasive power of the criterion of humankind as a basic value is fundamentally weakened. Such a historical experience leads to the loss of the human self subjectivity in its specifically human quality. It deprives civilised modern societies of their historical foundations and cannot possibly be integrated into the course of time in which past and future are seen as being held together by the unbroken validity of humaneness as a normative value. It destroys the continuity of a history in which civil subjectivity has inscribed its own universal norms.

What does it mean to face traumatic historical experiences? First and foremost, it means to realise that hitherto culturally dominant criteria of sense generation have lost their validity for historical discourse. ${ }^{23}$ But a loss is not a giving up. (Giving up the criteria of sense generation in historical discourse on the grounds of deconstructing ideology would mean the cultural suicide of modern subjectivity - a subjectivity that relies on the category of equality as the basis of mutual esteem in human relations.) Acknowledging a loss without recognising what has been lost leads back to the topic of mourning by history in a compelling way. At this point we are talking about historical mourning in the sense of humankind being confronted with the historical experience of drastic inhumanity. In this case mourning could lead to the recovery of one's self as a fundamental human. Mourning would have to consist of acknowledging the loss. This implies two aspects: first, to admit that humankind as a normative concept is lost or absent in historical experience, and, second, to accept that whatever has been lost remained as one's own (or better, has remained one's own in a new and different way).

What does this mean for the humankind criterion of historical identity? Humankind in the sense of the widest extension of modern subjectivity has been deprived of its historical significance, which has so far been regarded as part and parcel of one's own culture (or civilisation). It has died as a consequence of the historical experience of crimes against humankind, which are in 
effect crimes against the self (or better, its mental disposition). The self as defined in relation to humankind has died in the historical experience. Postmodernity has drawn a melancholic conclusion from this: it is no longer interested in the orientation towards humankind of modern subjectivity. ${ }^{24}$ Thus, it leaves the subject of modern societies disoriented and incapable of acting exactly at the point where its real-life context - in terms of political, social, economic and ecological issues - is characterised by its objective universality: in its demand for human rights and equality, as a regulating category of social conditions in the globalising process of capitalism and in the global danger for the natural resources of human life.

In contrast to this melancholy attitude, mourning would be a cultural achievement. The subject could recover its own human dimension by moving beyond the deadly experience of a civilisation rupture. This way of mourning would not simply incorporate this experience into culture, but would regard it as an effective stimulus to accentuate the validity of an orientation towards humankind in a passionate, yet disciplined and patient manner.

What do we mean by humankind re-appropriated by mourning? What do we mean by humankind that is present in its absence? Mankind is no longer a naturally justified fundamental value of human activity per se. In a historical discourse based on mourning, humankind has literally become utopian because it has lost its fixed and steadfast position in people's everyday world (Lebenswelt). As a consequence of its dislocation, it no longer can be taken as a plan for a world to be created (for that would correspond to an invocation of death and the designed world would be a phantom or ghost). As utopia, it would have an effusive, literally metaphysical status, beyond the reality of a civilised world. It would have to be taken as the yardstick for its criticism, a disturbing factor of insufficiency in respect to the achievements of civilisation.

But what do we mean by presence in its absence? Is it more than a shadow, a phantom of what could be, but unfortunately (because humans are so disposed) is not? In its absence, the notion of humankind could be no more than a conditional 'as if' of the human understanding the world and themselves. It could, however, take the effect of a mental driving force for human action, as a regulative concept for something that cannot be obtained, but can only be put into practice. It would not be transcendentally (as empirically based metaphysics) but transcendingly effective as a value-loaded medium of sense definitions. This may stimulate actions by serving as a guiding principle in the process of defining an aim. One could speak of fiction in the sense of a real conditional 'as if'. As lost, humankind is being reappropriated in the form of a standard aiming in the direction of an improving civilisation; and the fact that this has not yet been achieved urges man into action. The lost reliable and valid norms are retrieved as disturbance, criticism, utopia, and the motivation to keep one's own world moving in a direction indebted to these norms.

This example of mourning illustrates the fact that a deep emotion can be conceptualised into a historical category, which discloses new chances for future directed historical thinking with all its cognitive forces. 


\section{NOTES}

Acknowledgment: I would like to thank Damian Mac Con Uladh for his excellent help in correcting the English in this article.

1 Lao-Tse, Tao Te King: Das heilige Buch vom Weg und von der Tugend, chapter 69, transl. Günther Debon, Stuttgart: Reclam, 1961, p. 10 (my adaptation from the German version).

2 Leopold von Ranke, Vorlesungseinleitungen, ed. Volker Dotterweich and Walther Peter Fuchs (Aus Werk und Nachlaß, vol. IV), München: Oldenbourg, 1975, p. 185.

3 Ibid., p. 124.

4 I presume that we can even interpret these cases as examples of an interculturally widespread procedure of human historical consciousness in the interplay between emotion and cognition.

5 Immanuel Kant, Idee zu einer allgemeinen Geschichte in weltbürgerlicher Absicht, 1784, p. 388 (transl. T. M. Greene and H. Hudson). Cf. Jörn Rüsen, Following Kant: European Idea for a Universal History with an Intercultural Intent, in Groniek. Historisch Tijdschrift 160 (2003), pp. 359-368, also in Ex/Change. Newsletter of the Centre for Cross-Cultural Studies [City University of Hong Kong] 10 (2004), pp. 4-8; also in Bindu Puri and Heiko Sievers (eds), Terror, Peace, and Universalism. Essays on the Philosophy of Immanuel Kant. 200 Years of Immanuel Kant, Oxford: Oxford UP, 2007, pp. 111-121.

6 Ibid., p. 409.

7 Johann Gottfried Herder, Ideen zur Philosophie der Geschichte der Menschheit (Werke, ed. Wolfgang Pross, vol. III/I), Darmstadt: Wissenschaftliche Buchgesellschaft, 2002, pp. 579, 577.

8 Ibid. p. 594, 598 (my translation).

9 Georg Wilhelm Friedrich Hegel, Die Vernunft in der Geschichte, ed. Johannes Hoffmeister, 5th ed. Hamburg: Meiner, 1955, pp. $7 \mathrm{ff}$.

10 “. . . bloß zeigen, wie es eigentlich gewesen." Leopold von Ranke, Geschichten der romanischen und germanischen Völker von 1494-1514, in Sämtliche Werke, vol. 33, Leipzig: Duncker und Humblot, 1855, p. viii (my translation).

11 Marcel Proust, Remembrance of Things Past. Vol. 1: Swann's Way: Within a Budding Grove, transl. by C. K. Scott Moncrieff and Terence Kilmartin, New York: Vintage, 1982, pp. $48 \mathrm{ff}$.

12 Or, in German perception, Wahrnehmung, literally keeping the past true. Psychology teaches us that in each simple perception, an element of understanding, of meaning, is already present before the work of explicit thinking starts. Heidegger gave this pre-given openness of the human mind towards its world the remarkable term Lichtung. The light of sense and meaning shines already within the perception of the world; this gives emotions, which belong to the language of the senses, a grounding function in the mental work of the human mind, prefiguring its cognitive interpretation of what has been perceived.

13 Cf. Jörn Rüsen, Lebendige Geschichte. Grundzüge einer Historik III: Formen und Funktionen des historischen Wissens, Göttingen: Vandenhoeck \& Ruprecht, 1989.

14 Max Weber, "Die Wirtschaftsethik der Weltreligionen. Einleitung”, in idem, Gesammelte Aufsätze zur Religionssoziologie, vol. 1, Tübingen: J. C. B. Mohr (Paul Siebeck), 1922, p. 252.

15 I refer to an argumentation of mine which has already been partly published in Jörn Rüsen, "Trauma 
and Mourning in Historical Thinking", in Journal of Interdisciplinary Studies in History and Archaeology 1:1 (2004), pp. 10-21. For a more detailed presentation see the chapter on "Historisch trauern - Idee einer Zumutung” in Jörn Rüsen, Zerbrechende Zeit. Über den Sinn der Geschichte, Köln: Böhlau, 2001, pp. 301-324.

16 Cf. Jörn Rüsen, "Holocaust-Memory and Identity-Building: Metahistorical considerations in the case of (West-)Germany", in Michael S. Roth and Charles S. Salas (eds), Disturbing Remains: Memory, History, and Crisis in the Twentieth Century, Los Angeles: Getty Research Institute, 2001, pp. 252-270; idem, "Weiji, chuangshang yu rentong" [Crisis, Trauma, and Identity], in Zhongguo xueshu [China Scholarship] 3:2 (2002), pp. 15-38.

17 Dan Diner, "Zwischen Aporie und Apologie. Über Grenzen der Historisierbarkeit des Nationalsozialismus", in Dan Diner and Wolfgang Benz (eds), Ist der Nationalsozialismus Geschichte? Zu Historisierung und Historikerstreit, Frankfurt am Main: Fischer, 1987, pp. 62-73.

18 See my different approaches to this "breaking of time" in history in Jörn Rüsen, Zerbrechende Zeit.

19 Hayden White, Metahistory. The Historical Imagination in Nineteenth-Century Europe, Baltimore: Johns Hopkins UP, 1973; Frank R. Ankersmit, "Historical Representation”, in History and Theory 27 (1988), pp. 205-228; Frank R. Ankersmit, "Representation: History and Politics”, in Horst-Walter Blanke, Friedrich Jaeger and Thomas Sandkühler (eds), Dimensionen der Historik. Geschichtstheorie, Wissenschaftsgeschichte und Geschichtskultur heute. Jörn Rüsen zum 60. Geburtstag, Köln: Böhlau, 1998, pp. 27-40.

20 Cf. Jörn Rüsen, "Historical Thinking as Trauerarbeit. Burckhardt's Answer to Question of Our Time", in Andreas Cesana and Lionel Gossman (eds), Begegnungen mit Jacob Burckhardt (1818-1897) (= Beiträge zu Jacob Burckhardt 4), Basel: Schwabe (2004), pp. 337-355.

21 Cf. Klaus E. Müller, Der gesprungene Ring. Wie man Seele gewinnt und verliert, Frankfurt am Main: Otto Lembeck, 1997, pp. 68ff.; idem, "Sterben und Tod in den Naturvölkern”, in Hansjakob Becker, Bernhard Einig, and Peter-Otto Ullrich (eds), Im Angesicht des Todes. Ein interdisziplinäres Kompendium, St. Ottilien: EOS, 1987, pp. 49-89.

22 Frank R. Ankersmit, "The Sublime Dissociation of the Past: Or How to Be(come) what One is no Longer", in History and Theory 40 (2001), pp. 295-323.

23 This is how I read Dan Diner's "rupture of civilization" thesis. See fn. 17.

24 Karlheinz Bohrer brilliantly characterises the "attraction of "melancholic rhetoric" in human sciences as "a popular resting place where, due to the discourse on modernity that failed to move beyond the early stages, a frightened scientific community has, in the meantime, gathered strength for new quasi-teleological designs/ideas ..." See Karlheinz Bohrer, Der Abschied. Theorie der Trauer: Baudelaire, Goethe, Nietzsche, Benjamin, Frankfurt am Main: Suhrkamp, 1996, p. 40. He heroically holds "no future" (Zukunftslosigkeit) against the hopes for the future, but only in the form of a radical (and fortunately only a) poetic farewell to this time dimension in historical thinking. The question is to what extent his interpreting repetition and affirmation against all historical thinking can be read as a desperate attempt to delay this farewell real-historically. It corresponds with the title of his book, in which mourning categorically takes precedence over melancholy (without being justified by any objective reasons in his explanations). 